\title{
PENGARUH FRAKSI VOLUME FIBER SISAL (AGAVE SISALANA) TERHADAP KEKUATAN FLEKSURAL RESIN KOMPOSIT
}

Eko Hadianto ${ }^{\star}$,Liftia Layyinatus Syifa ${ }^{* *}$, Helmi Fathurrahman Hanafie ${ }^{* * *}$

\begin{tabular}{c}
\hline Keywords: \\
Composite Resin, Sisal \\
Fiber, Fiber Reinforced \\
Composite, Volume \\
fraction, Flexural \\
strength
\end{tabular}

\section{ABSTRACT}

Background: Composite resin is filling material that used in dentistry field because of good aesthetic. Use of fiber as reinforced composite resin (FRC) begins to be developed because it has a lot of functions, such as increase strength, stiffness, material hardness from fracture, and decrease shrinkage. Fiber composite resin has syntetic characteristic and needs chemical process also has an expensive price. Therefore, natural fiber is easier to find, cheaper and can be developed as an alternative substitute of syntetic fiber. One of the natural alternative is sisal fiber. This study aims to know the effect of volume fraction of sisal fiber to composite resin flexural strength with sisal fiber concentration $1 \%$, $2 \%, 3 \%, 4 \%$.

Method: This study was true experimental with post test only control group design which divided into 4 groups RK+FS 1\% (K1), RK+FS 2\% (K2), RK+FS $3 \%(\mathrm{~K} 3), \mathrm{RK}+\mathrm{FS} 4 \%(\mathrm{~K} 4)$. The data was analized using one way ANOVA assay and Post $\mathrm{Hoc}$ with significant degree $5 \%$.

Results: Mean of flexural strength sum $\mathrm{K} 1=50,87 \mathrm{MPa}, \mathrm{K} 2=42,96 \mathrm{MPa}$, $\mathrm{K} 3=33,94 \mathrm{MPa}, \mathrm{K} 4=24,32 \mathrm{MPa}$. Result of one way ANOVA assay showed value $p=0,000$. Result of further assay Post Hoc showed $K 1$ with $K 2 p=0,002$, $K 1$ with $\mathrm{K} 3 \mathrm{p}=0,000, \mathrm{~K} 1$ with $\mathrm{K} 4 \mathrm{p}=0,000, \mathrm{~K} 2$ with $\mathrm{K} 3 \mathrm{p}=0,001, \mathrm{~K} 2$ with $\mathrm{K} 4 \mathrm{p}=0,000, \mathrm{~K} 3$ with $\mathrm{K} 4 \mathrm{p}=0,000$.

Conclusions: Concluded that there is good effect of sisal fiber volume fraction to composite resin flexural strength. Flexural strength RK+FS $1 \%$ has higher strength than $\mathrm{RK}+\mathrm{FS} 2 \%, 3 \%, 4 \%$. Sisal fiber could become a natural fiber alternative in dentistry restoration material.

\section{PENDAHULUAN}

Resin komposit merupakan bahan tumpatan yang sering digunakan dalam bidang kedokteran gigi karena memiliki estetik baik ${ }^{1}$. Selain estetik yang baik, resin komposit memiliki biokompatibilitas, sifat perekat dan penanganan mudah dalam perawatan invasif pada rongga mulut ${ }^{2}$.

Resin komposit dibentuk oleh empat unsur utama yaitu: monomer organik atau polimer, partikel filler, coupling agen dan aktifator. Resin komposit dapat diklasifikasikan menurut ukuran partikel filler, sebagai berikut: resin komposit macrofill, microfill, hybrid dan nanofill. Partikel filler dapat meningkatkan kekerasan, mudah dimanipulasi dan mengurangi perubahan dimensi. Filler atau pengisi yang paling umum adalah silikat barium oksida, strontium, seng, alumunium dan zirconium ${ }^{2}$.

Material resin komposit memiliki sifat isotropis karena mengandung reinforced dengan filler partikulat sehingga dalam strukturnya tidak mempunyai arah filler khusus yang mengakibatkan sifat sama untuk semua arah filler ${ }^{3}$. Resin komposit yang diberi penguat fiber memiliki sifat anisotropis yaitu sifat yang tidak sama dalam semua arah. Penggunaan fiber sebagai penguat memiliki beberapa fungsi diantaranya meningkatkan

*Departemen Material Fakultas Kedokteran Gigi Universitas Islam Sultan Agung Semarang, **Program Pendidikan Dokter Gigi Fakultas Kedokteran Gigi Universitas Islam Sultan Agung Semarang, ${ }^{* \star}$ Departemen Prostodonsia Fakultas Kedokteran Gigi Universitas Islam Sultan Agung Semarang

Korespondensi : liftianavela@gmail.com 
kekuatan dan kekakuan, ketahanan bahan terhadap fraktur, serta menurunkan shrinkage. Pengujian kekuatan resin komposit flowable dengan partikel filler adalah 70-110 MPa, sedangkan jika ditambahkan fiber partikulat menjadi $133 \mathrm{Mpa}^{3}$.

Resin komposit dengan penambahan fiber sebagai penguat disebut fiber reinforced composite (FRC) ${ }^{3}$. Fabricated fiberyang sering digunakan pada kedokteran gigi diantaranya ultra high molecular weight polyethylene fiber (UHMWPE), glassfiber, aramid fiber, dan carbon/graphite ${ }^{4}$. Fiber sintetik membutuhkan proses kimiawi dalam proses produksinya dan harganya mahal. Oleh karena itu, digunakan fiber alami dari fiber alam yang mudah didapat dan murah sebagai alternatif yang dapat dikembangkan, salah satunya yaitu fiber sisal (Agave sisalana) ${ }^{5}$.

Keuntungan penggunaan fiber alami adalah jumlahnya melimpah, memiliki specific cost rendah, dapat didaur ulang dan diperbaharui (renewable) serta tidak mencemari lingkungan. Agave sisalana merupakan salah satu jenis tanaman penghasil fiber yang berasal dari daunnya sehingga tergolong tanaman fiber daun ${ }^{6}$.

Fiber sisal merupakan salah satu fiber alam yang mudah dibudidayakan dan banyak digunakan dalam bidang kelautan dan pertanian seperti pembuatan benang, jala, tali serta bahan - bahan kerajinan seperti tas. Fiber sisal memiliki sifat mekanik yang cukup baik sebagai material reinforced polymer sehingga dapat digunakan sebagai penguat basis gigi tiruan resin akrilik ${ }^{5}$.

Penelitian sebelumnya, menunjukkan bahwa kekuatan tarik (tensile strength) antara fiber sisal dan fiber glass terhadap resin komposit diperoleh kecenderungan menurun seiring dengan bertambahnya jumlah lapisan penguat fiber glass yang digantikan dengan fiber sisal terhadap 4 variasi spesimen dengan kode variasi fiber sisal (S) dan fiber glass $(F G)^{6}$. Tujuan dari penelitian ini adalah meneliti pengaruh fraksi volume fiber sisal terhadap kekuatan fleksural resin komposit. Dengan dilakukannya penelitian ini diharapkan dapat memberikan pengetahuan tentang pengaruh fraksi volume fiber sisal terhadap kekuatan fleksural resin komposit, selain itu juga sebagai kemajuan pengembangan ilmu kedokteran gigi serta dapat sebagai salah satu pilihan alternatif praktisi sebagai material bahan tumpatan yang memiliki spesific cost lebih rendah dibandingkan FRC partikulat

\section{METODE PENELITIAN}

Jenis penelitian analitik dengan rancangan penelitian true experimental dengan post test only control. Penelitian dilakukan pada 4 kelompok penelitian yaitu Resin Komposit + Fiber Sisal 1\% (K1), Resin Komposit + Fiber Sisal 2\% (K2), Resin Komposit + Fiber Sisal $3 \%(\mathrm{~K} 3)$, Resin Komposit + Fiber Sisal 4\% (K4).

Instrumen yang digunakan dalam penelitian ini meliputi: Universal Testing Machine (UTM), light curing unit, jangka sorong SIGMA 6, neraca analitik digital jewelry scale, plastis filling hand instrument, cetakan (Mould) stainless steel, pinset, glass slide, ball pointed, stopwatch, oven, gunting, cutter, inkubator, beaker glass, masker, handscoon, termometer, kompor, kuas, gunting. Bahanbahan penelitian meliputi: Resin komposit flowable nanofiller Filtek Z350TM XT, fiber sisal, silane coupling agent, aquades, larutan $\mathrm{CH}_{3} \mathrm{COOH} 6 \%$, larutan $\mathrm{NaOH} 6 \%$, silicon oil/ vaselin, etanol.

Penelitian diawali dengan proses
alkalisasi fiber sisal, dimulai dengan
pencucian dengan menggunakan etanol dan


dikeringkan dengan dimasukkan kedalam oven selama 10 menit dengan suhu $80^{\circ} \mathrm{C}$, kemudian dilakukan alkalisasi dengan cara direbus menggunakan larutan $\mathrm{NaOH} 6 \%$ selama 1 jam pada suhu $100^{\circ} \mathrm{C}$ kemudian didinginkan hingga suhu ruangan. Setelah itu dicuci dengan menggunakan aquades dan dilakukan netralisasi dengan direbus kembali menggunakan larutan $\mathrm{CH}_{3} \mathrm{COOH} 6 \%$ selama 1 jam pada suhu $100^{\circ} \mathrm{C}$ dan dikeringkan dengan memasukkan ke dalam oven selama 10 menit pada suhu $80^{\circ} \mathrm{C}$.

Tahap persiapan dengan cara mengambil satu persatu secara manual dengan menggunakan pinset utuk mendapatkan bentuk benang - benang kemudian dipotong sepanjang $40 \mathrm{~mm}$ kemudian dilakukan penimbangan dengan timbangan digital berdasarkan fraksi volume yang didapatkan dengan rumus berikut ini :

$$
\begin{aligned}
& V_{f}=V_{\text {serat }} \% \times V_{\text {cet }} \\
& M_{\mathrm{f}}=\rho_{\mathrm{f}} \mathrm{x}_{\mathrm{V}_{\mathrm{f}} \cdots \cdots \cdots} \ldots \ldots \\
& V_{m}=V_{m} \% \times V_{\text {cetak }} \\
& V_{\text {katalis }}=\frac{1}{100} \times V_{m} \ldots
\end{aligned}
$$

Keterangan :

$\mathrm{Vf} \quad=$ Volume fiber $\left(\mathrm{cm}^{\wedge} 3\right)$

Vfiber $\%=$ Volume fiber $(\%)$

Vcetak = Volume cetakan $\left(\mathrm{cm}^{\wedge} 3\right)$

Mf $\quad=$ Massa fiber (gr)

$\mathrm{Pf} \quad=$ Massa jenis fiber $\left(\mathrm{gr} / \mathrm{cm}^{\wedge} 3\right)$

$\mathrm{Vm} \quad=$ Volume resin $\left(\mathrm{cm}^{\wedge} 3\right)$

$\mathrm{Vm} \% \quad=$ Volume resin $(\%)$

Vkatalis $\quad=$ Volume katalis $\left(\mathrm{cm}^{\wedge} 3\right)$

Sehingga didapatkan hasil perhitungan berikut:

$$
\begin{aligned}
& 1 \%=0,015 \mathrm{gr} \\
& 2 \%=0,030 \mathrm{gr} \\
& 3 \%=0,045 \mathrm{gr} \\
& 4 \%=0,060 \mathrm{gr}
\end{aligned}
$$

Pembuatan Spesimen didalam Mould dengan Fiber Sisal dengan ketentuan panjang $40 \mathrm{~mm}$, lebar $5 \mathrm{~mm}$ dan tinggi $2 \mathrm{~mm}$. Cetakan yang tersedia diolesi tipis silicon oil sebagai media pemisah. Resin komposit flowable diambil dari tube kemudian diletakkan ke plat cetakan dan diratakan menggunakan plastis filling instrument. Selapis resin komposit nanofiller flowable diletakkan di dasar cetakan stainless steel. Bahan silane coupling agent ditetesi diatas glass slide. Fiber sisal yang telah disiapkan dibasahi bahan silane dan diletakkan didalam cetakan. Fiber dipegang dengan pinset kemudian diaplikasikan. Resin komposit diletakkan lagi hingga memenuhi cetakan. Setelah ditumpatkan, bagian atas cetakan diratakan dengan glass slide dan dilakukan penekanan ringan kemudian ditutup, kemudian lakukan light cure selama 20 detik. Setelah polimerisasi selesai, spesimen dibiarkan selama 60 menit. Letakan dalam inkubator selama 24 jam dan spesimen siap diuji.

Pengujian Kekuatan Fleksural Menggunakan Universal Testing Machine (UTM). Spesimen diletakkan pada alat uji dengan bending span $20 \mathrm{~mm}$. Loading piston tegak lurus dengan lebar spesimen. Spesimen diberikan beban dengan kecepatan crosshead $0,5 \mathrm{~mm} / \mathrm{mnt}$ sepanjang sumbu spesimen hingga spesimen fraktur tau hingga mencapai beban puncak. Hasil dilayar dicatat setelah alat berhenti membebani spesimen. Hasil pengujian kekuatan fleksural kemudian dihitung dengan menggunakan rumus:

$$
\sigma=(3 \mathrm{FL}) /\left(2 \mathrm{BH}^{2}\right)
$$

Dengan $=$

$$
\begin{array}{ll}
\sigma \quad & \text { Flexural strength }(\mathrm{MPa}) \\
\mathrm{F} & =\text { Beban maksimum diberikan pada } \\
\text { spesimen (kgf) } & \\
\mathrm{L} & =\text { Panjang span / support }(\mathrm{mm}) \\
\mathrm{B} & =\text { Lebar spesimen }(\mathrm{mm}) \\
\mathrm{H} & =\text { Ketebalan spesimen }(\mathrm{mm})
\end{array}
$$

Mencatat hasil perhitungan kekuatan fleksural resin komposit dengan fiber sisal 
selanjutnya dilakukan analisa data.

Analisis hasil penelitian data dimasukkan uji normalitas dengan uji shapiro-wilk. Uji homogenitas dilakukan dengan uji levene statistic. Setelah data yang didapat terdistribusi normal dan homogen maka dilanjutkan dengan analisa uji One Way ANOVA untuk mengetahui apakah ada pengaruh fraksi volume fiber sisal terhadap kekuatan fleksural resin komposit. Kemudian dilakukan uji Post Hoc Test yaitu LSD multi comparison untuk mengetahui kelompok yang memiliki perbedaan signifikan. Penelitian ini telah mendapat persetujuan dari Komisi Etik Penelitian Kesehatan dan Kedokteran Fakultas Kedokteran Gigi Universitas Islam Sultan Agung Semarang. Penelitian ini dilakukan di Laboratorium Fakultas Kedokteran Gigi UNISSULA Semarang.

\section{HASIL PENELITIAN}

Tabel 1. Nilai rata-rata dan standar deviasi kekuatan fleksural antara RK + FS dengan fraksi volume $1 \%-4 \%$

\begin{tabular}{cccc}
$\begin{array}{c}\text { Fraksi } \\
\text { volume } \\
\text { RK+FS }\end{array}$ & $\mathrm{N}$ & $\begin{array}{c}\text { Rata-rata } \\
(\mathrm{MPa})\end{array}$ & $\begin{array}{c}\text { Standar } \\
\text { Deviasi }\end{array}$ \\
$1 \%$ & 6 & 50,87 & 3,47 \\
\hline $2 \%$ & 6 & 42,96 & 4,49 \\
\hline $3 \%$ & 6 & 33,94 & 3,76 \\
\hline $4 \%$ & 6 & 24,32 & 3,43 \\
\hline
\end{tabular}

Tabel 2. Uji Post Hoc LSD kekuatan fleksural antara RK + FS dengan fraksi $1 \%-4 \%$

\begin{tabular}{ccc}
\hline $\begin{array}{c}\text { Fraksi volume } \\
\text { RK+FS }\end{array}$ & Selisih rata-rata & $p$ \\
\hline $1 \%$ dan $2 \%$ & 7,92 & 0,002 \\
\hline $1 \%$ dan $3 \%$ & 16,93 & $0,000^{2}$ \\
\hline $1 \%$ dan $4 \%$ & 26,55 & $0,000^{2}$ \\
\hline $2 \%$ dan $3 \%$ & 9,01 & 0,001 \\
\hline $2 \%$ dan $4 \%$ & 18,63 & $0,000^{2}$ \\
\hline $3 \%$ dan $4 \%$ & 9,61 & $0,000^{2}$ \\
\hline
\end{tabular}

Pada tabel 1 dapat disimpulkan bahwa terdapat perbedaan nilai rata-rata kekuatan fleksural dari keempat kelompok perlakuan. Kekuatan fleksural RK + FS 1\% (50,87 MPa \pm 3,47) lebih tinggi dari 3 kelompok lainnya. Sedangkan RK + FS 4\% (24,32

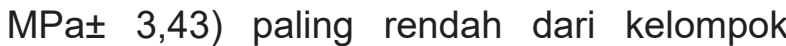
lainnya. Setelah dilakukan uji normalitas dan homogenitas didapatkan data yang normal dan homogen untuk selanjutnya dilakukan uji One Way ANOVA. Hasil uji One Way ANOVA menunjukkan adanya perbedaan yang signifikan dari hasil rata-rata ketiga kelompok dengan $p$ value $<0,05$.

Pada tabel 2. menunjukkan bahwa pada uji Post Hoc LSD kekuatan fleksural RK + FS dengan fraksi $1 \%$ - 4\% menunjukkan terdapat perbedaan bermakna antar kelompok spesimen perlakuan.

\section{DISKUSI}

Hasil penelitian tentang ada atau tidaknya pengaruh fraksi volume fiber sisal terhadap kekuatan fleksural resin komposit menunjukkan bahwa pada masing - masing kelompok perlakuan terdapat perbedaan bermakna antara RK + FS 1\%, RK + FS 2\%, RK + FS $3 \%$, dan RK + FS 4\%.

Nilai kekuatan fleksural pada kelompok RK + FS 1\% paling tinggi dibandingkan kelompok lainnya dengan nilai rata-rata kekuatan fleksural 50,87 Mpa. Fiber sisal yang ditambahkan dalam resin komposit dapat meningkatkan kekuatan fleksural jika ketebalan fiber sisal tersebut ideal dan mampu melakukan adhesi interface secara baik, sehingga dapat menahan serta menghambat tekanan yang diterima yang berdampak pada peningkatkan kekuatan fleksural resin komposit ${ }^{7}$.

Rendahnya kekuatan RK + FS 2\%, RK + FS $3 \%$ dan RK + FS 4\% dibandingkan RK + FS 1\% 
diduga karena rasio fiber dan komposit yang digunakan pada perlakuan tidak seimbang antara fiber dan resin komposit sehingga tidak mampu mengisi fiber dengan sempurna.

Ketidakseimbangan rasio fiber dan komposit yang menyebabkan ketidakmampuan komposit mengisi fiber dengan sempurna mengakibatkan kekuatan fleksural menjadi rendah. Hal ini sesuai dengan penelitian sebelumnya yang menyatakan penambahan fiber mampu meningkatkan kekuatan fleksural, akan tetapi jika melampaui nilai optimum maka penambahan fiber akan cenderung menyebabkan penurunan kekuatan mekanis dikarenakan resin tidak mampu berkontak rapat dengan fiber sehingga berakibat nilai energi serap menurun ${ }^{8}$.

Pada uji lanjutan LSD, terlihat adanya perbedaan yang bermakna antar kelompok perlakuan RK + FS 1\%, RK + 2\%, RK + FS $3 \%$ dan RK + FS 4\%. Hal ini diduga karena perbedaan ketebalan resin komposit dan fiber yang digunakan, pembasahan bahan adhesif, dan polimerisasi yang kurang sempurna.

Ketebalan resin komposit serta fiber sebagai pengisi yang berbeda antar kelompok perlakuan menjadi penyebab perbedaan kekuatan fleksural yang dihasilkan ${ }^{7}$. Pada penelitian ini RK + FS 1\% memiliki \% berat fiber paling rendah dan memiliki ketebalan resin komposit yang paling tinggi, kemudian diikuti RK + FS 2\%, RK FS 3\%, dan RK FS $4 \%$. Ketebalan resin komposit dan fiber yang digunakan menyebabkan perbedaan kekuatan sehingga dapat diasumsikan berat yang berbeda pada setiap spesimen dalam kelompok menghasilkan kekuatan fleksural yang berbeda pula, hal tersebut sesuai dengan penelitian Syuhada, yang menyatakan bahwa \% resin komposit yang sama dapat memberikan kekuatan fleksural yang hampir sama pula ${ }^{9}$.
Bahan adhesif yang digunakan dalam penelitian juga dapat berpengaruh terhadap perbedaan yang bermakna antar kelompok perlakuan. Semakin tebal fiber yang digunakan dalam spesimen maka bahan adhesif tidak mampu membasahi fiber dengan sempurna sehingga mempengaruhi kekuatan fleksural yang berbeda pula, hal tersebut sesuai yang dikemukakan Martha bahwa pembasahan yang tidak sempurna menyebabkan perlekatan tidak baik sehingga dapat menurunkan kekuatan fleksural ${ }^{4}$.

Selain itu, polimerisasi yang tidak sempurna juga menjadi faktor penyebab terjadinya perbedaan yang bermakna antar perlakuan. Ketebalan fiber yang berbeda antar kelompok menyebabkan pada saat resin komposit dipolimerisasi memiliki hasil yang berbeda pula. Semakin tebal fiber maka resin komposit bagian tensile base akan semakin jauh dari sinar karena terhalang oleh fiber. Hal tersebut menyebabkan resin tidak terpolimerisasi secara sempurna sehingga berpengaruh pula terhadap kekuatan mekanik yang semakin menurun, selaras dengan penelitian Susanto menyatakan bahwa polimerisasi yang tidak sempurna karena ketebalan bahan dan lamanya waktu penyinaran resin komposit berpengaruh besar menurunkan kekuatan, kekerasan serta stabilitas warna resin komposit $^{10}$.

\section{KESIMPULAN}

Berdasarkan penelitian yang telah dilakukan menunjukan bahwa terdapat pengaruh fraksi volume fiber sisal terhadap kekuatan fleksural resin komposit. Kekuatan fleksural resin komposit dengan fraksi volume fiber sisal 1\% memiliki kekuatan fleksural lebih tinggi dibandingkan dengan resin komposit dengan fraksi volume fiber sisal $2 \%, 3 \%$ dan 
$4 \%$ sehingga dapat dijadikan alternatif pilihan

dalam penggunaan fiber alami sebagai bahan

restorasi dalam bidang kedokteran gigi.

\section{DAFTAR PUSTAKA}

1. Putriyanti F, Herda E, Soufyan A. Strength Micro Fine Hybrid Resin Composite Yang Direndam Dalam Minuman Isotonic. Jurnal PDGI. 2012. 61(1):43-8.

2. García-Contreras R, Scougall-Vilchis R, Acosta-Torres L, Arenas-Arrocena M, GarcíaGarduño R, Fuente-Hernández J de la. Vickers microhardness comparison of 4 composite resins with different types of filler . Jurnal Oral Research. 2014 : 313-20.

3. Septommy C, Widjijono, Dharmastiti R. Pengaruh posisi dan fraksi volumetrik fiber polyethylene terhadap kekuatan fleksural fiber reinforced composite. Dental Journal. 2014. 47(1):52-6.

4. Martha M, Herda E, Soufyan A. Pemilihan resin komposit dan fiber untuk meningkatkan kekuatan fleksural Fiber Reinforced Composite ( FRC ). Jurnal PDGI. 2010. 59(1):29-34.

5. Hadianto E, Widjijono, Herliansyah MK. Pengaruh Penambahan Polyethylene Fiber Dan Fiber Sisal Terhadap Kekuatan Flek- sural Dan Impak Base Plate Komposit Resin Akrilik. Insisiv Dental Journal. 2013. 2(2):57-67.

6. Yudhanto F, Sudarisman, Ridlwan M. Karakterisasi Kekuatan Tarik Komposit Hybrid Lamina Fiber Anyam Sisal Dan Gelas Diperkuat Polyester. Jurnal IImu Semesta Teknika. 2016 19(May):48-54

7. Chianelli-Junior R, Reis JML, Cardoso JL, Castro PF. Mechanical characterization of sisal fiberreinforced recycled HDPE composites. Materials Research. 2013. 16(6):1393-7.

8. Sujito, Sudarmadji, Purwandari E. Pengembangan Bahan Komposit Ramah Lingkungan Berpenguat Fiber Ampas Tebu dan Resin Biodegradable. Jurnal MIPA Uniersitas Jember. 2014;1-12.

9. Syuhada A. Pengaruh Fraksi Volume Fiber Ampas Tebu. Jurnal Universitas Syiah Kuala. $2014: 1-60$.

10. Susanto AA. Pengaruh ketebalan bahan dan lamanya waktu penyinaran terhadap kekerasan permukaan resin komposit sinar.Dental Journal. 2005. 38:32-5. 